\title{
Xenotransplantation of Porcine Islet Cells as a Potential Option for the Treatment of Type 1 Diabetes in the Future
}

\author{
Authors \\ B. Reichart ${ }^{1}$, H. Niemann ${ }^{2}$, T. Chavakis ${ }^{3,4,5,6}$, J. Denner ${ }^{7}$, E. Jaeckel ${ }^{8}$, B. Ludwig ${ }^{3,4,9}$, G. Marckmann ${ }^{10}$, \\ A. Schnieke ${ }^{11}$, R. Schwinzer ${ }^{12}$, J. Seissler ${ }^{13}$, R. R. Tönjes ${ }^{14}$, N. Klymiuk ${ }^{15}$, E. Wolf ${ }^{15}$, S. R. Bornstein ${ }^{3,4,9,16}$ \\ Affiliations \\ Affiliation addresses are listed at the end of the article
}

Key words

- diabetes mellitus type 1

- xenotransplantation

islet cells received 23.09.2014

accepted 20.10.2014

\section{Bibliography}

DOI http://dx.doi.org/

10.1055/s-0034-1395518

Published online:

December 15, 2014

Horm Metab Res 2015;

47: 31-35

(c) Georg Thieme Verlag KG

Stuttgart · New York

ISSN 0018-5043

Correspondence

Prof. Dr. med. S. R. Bornstein

Medizinische Klinik und

Poliklinik III

Technische Universität Dresden Universitätsklinikum Carl

Gustav Carus

Fetscherstrasse 74

01307 Dresden

Tel.: + 49/351/458 5955

Fax: +49/351/458 6398

Stefan.Bornstein@uniklinikum-

dresden.de

\section{Abstract}

$\nabla$

Solid organ and cell transplantation, including pancreatic islets constitute the treatment of choice for chronic terminal diseases. However, the clinical use of allogeneic transplantation is limited by the growing shortage of human organs. This has prompted us to initiate a unique multi-center and multi-team effort to promote translational research in xenotransplantation to bring xenotransplantation to the clinical setting. Supported by the German Research Foundation, an interdisciplinary group of surgeons, internal medicine doctors, diabetologists, material sciences experts, immunologists, cell biologists, virologists, veterinarians, and geneticists have established a collaborative research center (CRC) focusing on the biology of xenogeneic cell, tissue, and organ transplantation. A major strength of this consortium is the inclusion of members of the regulatory bodies, including the Paul-Ehrlich

\section{Introduction}

\section{$\nabla$}

Type 1 diabetes and novel therapeutic strategies

The prevalence of type 1 diabetes in Western Europe and North America is about $0.5 \%$ of the population, with an increasing trend, and now affecting approximately 2 million subjects [1]. Type 1 diabetes pathogenesis involves a complex autoimmune reaction leading to complete destruction of the insulin-producing beta-cells of the pancreas. Consequently, the disease requires life-long substitution with insulin [2]. Despite insulin therapy, the serious and potentially lifethreatening complications of the disease make it imperative to develop a curative therapeutic approach for the treatment of type 1 diabetes. In this context, preventive strategies aiming at the protection of islets, for example, by blocking inflammation, as well as approaches to induce
Institute (PEI), infection specialists from the Robert Koch Institute and PEI, veterinarians from the German Primate Center, and representatives of influential ethical and religious institutions. A major goal of this consortium is to promote islet xenotransplantation, based on the extensive expertise and experience of the existing clinical islet transplantation program. Besides comprehensive approaches to understand and prevent inflammation-mediated islet xenotransplant dysfunction [immediate blood-mediated inflammatory reaction (IBMIR)], we also take advantage of the availability of and experience with islet macroencapsulation, with the goal to improve graft survival and function. This consortium harbors a unique group of scientists with complementary expertise under a cohesive program aiming at developing new therapeutic approaches for islet replacement and solid organ xenotransplantation.

the regeneration of islet cell mass and function have been proposed [3]. Moreover, beta cell replacement therapies have been developed, including the transplantation of either the complete pancreas or isolated islets. Restoration of the islet cell mass by allogeneic islet transplantation represents a therapeutic option especially in type 1 diabetes patients with a very labile metabolic situation $[4,5]$. This technique has been successfully established in routine clinical practice at few specialized centers. Although allotransplantation of whole pancreas or islets appears to be promising for the treatment of type 1 diabetes, there are still major limitations, mainly resulting from shortage of donor supply and the relatively high number of islet cells required for a single patient, as well as complications associated with islet transplantation, such as infections $[6,7]$. 
To combat the disease, autologous stem-cell based therapies, for example, by reprogramming differentiated somatic cells into pluripotent cells [8] or by controlled differentiation of pluripotent cells $[9,10]$ have been proposed. This would not only help overcome the limited resources of differentiated cells but also avoid the potential complications associated with the otherwise required immunosuppression for allogeneic transplants. However, such approaches may bear the risk of the tumorigenic potential associated with pluripotent stem cells $[11,12]$. Therefore, stem cell-based attempts may not compensate for the prevalent shortage of donor organs in the near future.

\section{Xenotransplantation}

As an alternative therapeutic approach, xenogeneic islet transplantation has been experimentally performed in preclinical diabetic animal models with promising results. It may therefore represent a promising approach to overcome donor organ shortage [13-17]. First clinical trials have evaluated the efficacy and microbiological safety [18-23]. In one trial, live encapsulated porcine islet cells were found 9.5 years after transplantation [24].

The unique advantage of xenotransplantation is the potentially unlimited availability of donor organs on demand. The ideal donor xenotransplant should have a similar size and physiology as well as a similar anatomic location compared to the human organ. These criteria are largely fulfilled by the pig (Sus scrofa) and in addition, this species has a relatively short generation time of about 4 months, and is highly fertile. Furthermore, genetic engineering is well established in the pig, thus providing an opportunity to genetically modify and optimize the donor xenotransplant for better matching with the human host. Considerable progress has been made to produce genetically modified pig organs for nonhuman primate xenotransplantation [25-28].

However, the social and ethical acceptance of animals as donors of xenotransplants has to be clarified $[29,30]$. Additionally, serious safety concerns have been raised by the possibility of transmitting infectious pathogens from the donor species to the human patient, although preventive actions like housing and breeding of donor animals under specific pathogen-free (SPF) conditions and screening of the donor prior to transplantation are expected to minimize infectious risks [31-33]. Wynyard et al. [23] reported the case of 14 patients from New Zealand with severe unaware hypoglycemia, who were treated with microencapsulated porcine islets. Up to 52 post-transplant weeks, no transmission of either PERV or other porcine microorganisms was detected by sensitive PCR and immunological methods. However, in addition to the risk posed by PERV [34], other viruses also need to be considered, which are difficult to eliminate even under SPF production of pigs, for example, hepatitis $\mathrm{E}$ virus and herpes viruses [31]. In order to implement the highest possible safety standards, the International Xenotransplantation Association (IXA) has established guidelines for xenotransplantation $[35,36]$.

\section{Strategies to accomplish immunological tolerance of pig xenotransplants}

Rejection of porcine xenotransplants by the human immune system is mediated via a series of humoral and cellular mechanisms. The hyperacute rejection (HAR) results from pre-formed antibodies directed against the $\alpha 1,3$-galactosyl-galactose ( $\alpha \mathrm{Gal}$ ) epitopes on porcine endothelial cells. The generation of immune complexes induces a fulminant activation of the host comple- ment system with rapid disruption of the graft endothelial system and irreversible organ damage within a few hours. Interestingly, xenotransplantation experiments with grafts from genetically engineered pigs lacking functional $\alpha 1,3-$ galactosyltransferase (GGTA1, also termed as $\alpha 1,3 \mathrm{GT}$ ) genes, thereby being devoid of the $\alpha$ Gal-epitope, have yielded promising results with regard to enhanced graft survival and function in baboons [37-39].

The porcine xenotransplants are challenged by the acute humoral xenotransplant rejection (AHXR; also known as acute vascular rejection or delayed xenotransplant rejection), which is primarily induced by the existence of pre-formed antibodies (presumably directed against the porcine endothelial Neu5Gcepitope). Strategies to prevent the humoral xenotransplant rejection are based on the production of transgenic animals lacking the immunologically relevant epitopes or expressing human complement regulatory proteins (e.g., CD46, CD55, CD59) on endothelial cells [40] or other human immunological proteins involved in endothelial activation such as heme oxygenase 1 (HO-1) [41] or tumor necrosis factor induced human protein A20 [42]. Furthermore, expression of human antithrombotic or anticoagulant genes such as tissue factor pathway inhibitor (TFPI), endothelial protein C receptor (EPCR) or thrombomodulin (TM) may also enhance xenotransplant survival [43].

Since islet preparations usually contain only little or no endothelial cells and vascular structures, cellular graft reactions (CXR) play the dominant role in islet xenotransplant rejection. Blocking T-cell activation by antigen presenting cells (APC) via interfering with the co-stimulatory systems CD40-CD40L and/or CD80/86-CD28 could be utilized to reduce CXR $[15,16,40,44,45]$. After xenotransplantation under the kidney capsule, transgenic porcine islet cell clusters expressing the $\mathrm{T}$ cell costimulation blocking molecule LEA29Y normalized blood glucose levels of diabetic immuno-deficient mice and were, in contrast to wildtype porcine islets, protected against rejection by human immune cells [46]. T cell activation is regulated not only by costimulatory but also by co-inhibitory receptor-ligand interactions. Thus, enhancing inhibitory signals, for example, by transgenic expression of respective ligands on porcine cells and tissues, is an attractive new concept to diminish human anti-pig cellular immune responses [47]. The observation that immune responses to pig cells overexpressing the human inhibitory ligand PD-L1 (CD274) are particularly weak in vitro and in vivo supports the relevance of this approach $[48,49]$. Combining blockade of co-stimulatory signaling pathways (e.g., by CTLA-4. Ig/LEA29Y) with an enhancement of inhibitory signals by targeting the PD-1/PD-L1 pathway should be highly effective in controlling cell-mediated rejection of xenotransplants. Another feasible approach to inhibit T-cell mediated graft rejection appears to be the induction of regulatory T-cells (Tregs) [50], although the relevance of Tregs in xeno graft rejection requires further evaluation [51]. Also, natural killer (NK) cells, macrophages and neutrophils are critical components of the cellular response in xenotransplant rejection [52-54]. For example, expression of HLA-E, an inhibitor of NK cell activation has been found to protect porcine cells from destruction by primate NK cells [55]. Other promising targets to protect xenotransplants (porcine Islets) from host-directed lysis are associated with the so-called immediate blood-mediated inflammatory reaction (IBMIR) $[56,57]$ and the resulting activation of complement factors and coagulation [57]. 
In conclusion, experimental xenograft transplantation from genetically modified pigs or pharmacologic modification of HAR, AHXR, CXR, and IBMIR appear to be promising strategies to improve graft survival.

\section{Macroencapsulation for xenogeneic transplantation}

The requirement of chronic immunosuppression to prevent graft rejection bearing several risks for the host is a major limitation for beta cell replacement. In order to overcome these obstacles, micro- and macro-encapsulation appear to be reasonable strategies to separate the graft from the host immune system and prevent rejection [58]. For example, Dufrane et al. [14] described the successful xenotransplantation of alginate-encapsulated porcine islets into a streptozotocin-induced diabetic animal model. In this setting, glycemic control could be accomplished over several months in animals transplanted with encapsulated islets without immunosuppression, while nonencapsulated islets were rejected within a week. Furthermore, Ludwig et al. $[59,60]$ developed a subcutaneously implantable macrochamber system containing alginate-immobilized islets that are protected from the host immune system by a permeable Teflon membrane. In addition, this device contains a refillable oxygen chamber system to provide the islets with oxygen. This system has been optimized and subcutaneous implantation of the macro-chamber system containing immobilized rat islets in diabetic mini-pigs resulted in persistent glycemic control over 3 months without immunosuppression, demonstrating a sustained xenotransplant function $[61,62]$. In addition, this macro-chamber system has been successfully used for the transplantation of human islets without immunosuppression in a pilot-study conducted in a patient with type-1-diabetes [63].

These data indicate that macroencapsulation of islets may be a promising approach to prevent graft rejection in allo- and xenogeneic beta cell replacement therapies.

\section{Summary}

Many specific hurdles and obstacles related to the field of xenotransplantation have been identified and this knowledge has paved the way for the development of a variety of encouraging concepts utilizing porcine xenotransplants for beta cell replacement. Considering the enormous recent progress in our understanding of immunological mechanisms, the transfer of genetic engineering techniques into routine practice and the advances in material sciences, medical engineering and technology, xenotransplantation of pancreas or islets appears to be a promising approach for the treatment of type 1 diabetes.

\section{Conflict of Interest}

$\nabla$

The authors declare that they have no conflicts of interest in the authorship or publication of this contribution.

\footnotetext{
Affiliations

${ }^{1}$ Institute for Surgical Research at the Walter-Brendel-Centre for Experimental Medicine, Ludwig-Maximilians-University, Munich, Germany

Friedrich-Loeffler-Institute Mariensee, Federal Research Institute for Animal

Health, Neustadt, Germany
}

${ }^{3}$ Department of Medicine III, University Hospital Carl Gustav Carus, Dresden, Germany

${ }^{4}$ Centre for Diabetes Research, Paul Langerhans Institute Dresden, Dresden, Germany

${ }^{5}$ Department of Clinical Pathobiochemistry, Technische Universität Dresden, Dresden, Germany

${ }^{6}$ Institute for Clinical Chemistry and Laboratory Medicine, Technische Universität Dresden, Dresden, Germany

${ }^{7}$ Robert-Koch-Institute, Berlin, Germany

${ }^{8}$ Medical School of Hannover, Department Gastroenterology, Hepatology, Endocrinology, Diabetology, Hannover, Germany

Center for Regenerative Therapies Dresden, Technische Universität Dresden, Dresden, Germany

${ }^{10}$ Institute for Ethics, History and Theory of Medicine, Ludwig-

Maximilians-University, Munich, Germany

${ }^{11}$ Chair of Livestock Biotechnology, Technical University of Munich, Freising, Germany

${ }^{12}$ Transplant Laboratory, Clinic for General,- Visceral-, and Transplantation Surgery, Hannover Medical School, Hannover, Germany

3 Medizinische Klinik und Poliklinik IV, Diabetes Zentrum, LudwigMaximilians-University, Munich, Germany

${ }^{14}$ Paul-Ehrlich-Institute, Federal Institute for Vaccines and Biomedicines, Langen, Germany

${ }^{15}$ Gene Center, Molecular Animal Breeding and Biotechnology, LudwigMaximilians-University, Munich, Germany

${ }^{16}$ Department of Endocrinology and Diabetes, King's College, London, England

\section{References}

1 Ludwig B, Barthel A, Reichel A, Block NL, Ludwig S, Schally AV, Bornstein $S R$. Modulation of the pancreatic islet-stress axis as a novel potential therapeutic target in diabetes mellitus. Vitam Horm 2014; 95: 195-222

2 Achenbach P, Bonifacio E, Koczwara K, Ziegler AG. Natural history of type 1 diabetes. Diabetes 2005; 54 (Suppl 2): S25-S31

3 Meier JJ. Beta cell mass in diabetes: A realistic therapeutic target? Diabetologia 2008; 51: 703-713

4 Ludwig B, Reichel A, Kruppa A, Ludwig S, Steffen A, Weitz J, Bornstein $S R$. Islet transplantation at the Dresden Diabetes Center: five years' experience. Horm Metab Res 2015; 47: 4-8

5 Collaborative Islet Transplant Registry (CITR). www.citregistry.org

6 Zimmerhackl LB, Jungraithmayr TC, Tibell A. Marginal donors in pediatric solid organ transplantation. Pediatric transplantation 2010; 14 : 154-155

7 Morris MI, Fischer SA, Ison MG. Infections transmitted by transplantation. Infect Dis Clin North Am 2010; 24: 497-514

8 Takahashi $K$, Yamanaka $S$. Induction of pluripotent stem cells from mouse embryonic and adult fibroblast cultures by defined factors. Cell 2006; 126: 663-676

9 Laflamme MA, Murry CE. Heart regeneration. Nature 2011; 473: 326-335

10 Weissman IL, Shizuru JA. The origins of the identification and isolation of hematopoietic stem cells, and their capability to induce donorspecific transplantation tolerance and treat autoimmune diseases. Blood 2008; 112: 3543-3553

11 Huang $P$, He Z, Ji S, Sun H, Xiang D, Liu C, Hu Y, Wang X, Hui L. Induction of functional hepatocyte-like cells from mouse fibroblasts by defined factors. Nature 2011; 475: 386-389

12 Vierbuchen T, Ostermeier A, Pang ZP, Kokubu Y, Sudhof TC, Wernig M. Direct conversion of fibroblasts to functional neurons by defined factors. Nature 2010; 463: 1035-1041

13 van der Windt DJ, Bottino R, Casu A, Campanile N, Smetanka C, He J, Murase N, Hara H, Ball S, Loveland BE, Ayares D, Lakkis FG, Cooper $D K C$, Trucco $M$. Long-term controlled normoglycemia in diabetic nonhuman primates after transplantation with hCD46 transgenic porcine islets. Am J Transplant 2009; 9: 2716-2726

14 Dufrane D, Goebbels RM, Gianello P. Alginate macroencapsulation of pig islets allows correction of streptozotocin-induced diabetes in primates up to 6 months without immunosuppression. Transplantation 2010; 90: 1054-1062

15 Cardona K, Korbutt GS, Milas Z, Lyon J, Cano J, Jiang W, Bello-Laborn $H$, Hacquoil B, Strobert E, Gangappa S, Weber CJ, Pearson TC, Rajotte $R V$, Larsen $C P$. Long-term survival of neonatal porcine islets in nonhuman primates by targeting costimulation pathways. Nat Med 2006; 12: $304-306$ 
16 Hering BJ, Wijkstrom M, Graham ML, Hardstedt M, Aasheim TC, Jie T, Ansite JD, Nakano M, Cheng J, Li W, Moran K, Christians U, Finnegan $C$, Mils CD, Sutherland DE, Bansal-Pakala P, Murtaugh MP, Kirchof N, Schurman $\mathrm{H}-\mathrm{J}$. Prolonged diabetes reversal after intraportal xenotransplantation of wild-type porcine islets in immunosuppressed nonhuman primates. Nat Med 2006; 12: 301-303

17 Elliott RB. Towards xenotransplantation of pig islets in the clinic. Curr Opin Organ Transplant 2011; 16: 195-200

18 Elliott RB, Escobar L, Garkavenko O, Croxson MC, Schroeder BA, McGregor $M$, Ferguson G, Beckman N, Ferguson S. No evidence of infection with porcine endogenous retrovirus in recipients of encapsulated porcine islet xenografts. Cell Transplant 2000; 9: 895-901

19 Garkavenko O, Croxson MC, Irgang M, Karlas A, Denner J, Elliott RB. Monitoring for presence of potentially xenotic viruses in recipients of pig islet xenotransplantation. J Clin Microbiol 2004; 42: 5353-5356

20 Valdés-González RA, Dorantes LM, Garibay GN, Bracho-Blanchet E, Mendez AJ, Dávila-Pérez R, Elliott RB, Terán L, White DJ. Xenotransplantation of porcine neonatal islets of Langerhans and Sertoli cells: a 4-year study. Eur J Endocrinol 2005; 153: 419-427

21 Tuch BE, Keogh GW, Williams LJ, Wu W, Foster JL, Vaithilingam V, Philips $R$. Safety and viability of microencapsulated human islets transplanted into diabetic humans. Diabetes Care 2009; 32: 1887-1889

22 Basta G, Montanucci P, Luca G, Boselli C, Noya G, Barbaro B, Qi M, Kinzer $K P$, Oberholzer J, Calafiore R. Long-term metabolic and immunological follow-up of nonimmunosuppressed patients with type 1 diabetes treated with microencapsulated islet allografts: four cases. Diabetes Care 2011; 34: 2406-2409

23 Wynyard S, Nathu D, Garkavenko O, Denner J, Elliott R. Microbiological safety of the first clinical pig islet xenotransplantation trial in New Zealand. Xenotransplantation 2014; 21: 309-323

24 Elliott RB, Escobar L, Tan PL, Muzina M, Zwain S, Buchanan C. Live encapsulated porcine islets from a type 1 diabetic patient $9.5 \mathrm{yr}$ after xenotransplantation. Xenotransplantation 2007; 14: 157-161

25 Ekser B, Ezzelarab M, Hara $H$, van der Windt DJ, Wijkstrom M, Bottino $R$, Trucco $M$, Cooper DK. Clinical xenotransplantation: the next medical revolution? Lancet 2012; 379: 672-683

26 Cooper DK, Satyananda V, Ekser B, van der Windt DJ, Hara H, Ezzelarab $M B$, Schuurman HJ. Progress in pig-to-non-human primate transplantation models (1998-2013): a comprehensive review of the literature. Xenotransplantation 2014; 21: 397-419

27 Nagaraju S, Bottino R, Wijkstrom $M$, Trucco $M$, Cooper DK. Islet xenotransplantation: what is the optimal age of the islet-source pig? Xenotransplantation 2014, Aug 11 doi:10.1111/xen.12130 [Epub ahead of print]

28 Mohiuddin MM, Singh AK, Corcoran PC, Hoyt RF, Thomas ML $3^{\text {rd }}$, Lewis $B G$, Eckhaus M, Reimann KA, Klymiuk N, Wolf E, Ayares D, Horvath KA. One-year heterotopic cardiac xenograft survival in a pig to baboon model. Am J Transplant 2014; 14: 488-489

29 Cozzi E, Tallacchini M, Flanagan EB, Pierson RN $3^{\text {rd }}$, Sykes $M$, Vanderpool HY. The International Xenotransplantation Association consensus statement on conditions for undertaking clinical trials of porcine islet products in type 1 diabetes - chapter 1: Key ethical requirements and progress toward the definition of an international regulatory framework. Xenotransplantation 2009; 16: 203-214

30 Katholische Akademie Bayern. www.kath-akademie-bayern.de Zur Debatte, Heft 63/2014

31 Mueller NJ, Takeuchi Y, Mattiuzzo G, Scobie L. Microbial safety in xenotransplantation. Curr Opin Organ Transplant 2011; 16: 201-206

32 Scobie L, Takeuchi Y. Porcine endogenous retrovirus and other viruses in xenotransplantation. Curr Opin Organ Transplant 2009; 14: 175-179

33 Semaan M, Rotem A, Barkai U, Bornstein S, Denner J. Screening pigs for xenotransplantation: prevalence and expression of porcine endogenous retroviruses in Göttingen minipigs. Xenotransplantation 2013; 20: $148-156$

34 Denner J, Tönjes RR. Infection barriers to successful xenotransplantation focusing on porcine endogenous retroviruses. Clin Microbiol Rev 2012; 25: 318-343

35 Denner J, Schuurman HJ, Patience C. The International Xenotransplantation Association consensus statement on conditions for undertaking clinical trials of porcine islet products in type 1 diabetes-chapter 5: Strategies to prevent transmission of porcine endogenous retroviruses. Xenotransplantation 2009; 16: 239-248

36 Denner J, Tönjes R, Takeuchi Y, Fishman J, Linda Scobie L. The International Xenotransplantation Association consensus statement on conditions for undertaking clinical trials of porcine islet products in type 1 diabetes - Chapter 5: Recipient monitoring and response plan for preventing disease transmission. Xenotransplantation in preparation
37 Yamada K, Yazawa K, Shimizu A, Iwanaga T, Hisashi Y, Nuhn M, O'Malley $P$, Nobori S, Vagefi PA, Patience C, Fishman J, Cooper DK, Hawley RJ, Greenstein J, Schuurman HJ, Awwad M, Sykes M, Sachs DH. Marked prolongation of porcine renal xenograft survival in baboons through the use of alpha1,3-galactosyltransferase gene-knockout donors and the cotransplantation of vascularized thymic tissue. Nat Med 2005; 11: $32-34$

38 Kuwaki K, Tseng YL, Dor FJ, Shimizu A, Houser SL, Sanderson TM, Lancos CJ, Prabharasuth DD, Cheng J, Moran K, Hisashi Y, Mueller N, Yamada K, Greenstein JL, Hawley RJ, Patience C, Awwad M, Fishman JA, Robson SC, Schuurman HJ, Sachs DH, Cooper DK. Heart transplantation in baboons using alpha1,3-galactosyltransferase gene-knockout pigs as donors: initial experience. Nat Med 2005; 11: 29-31

39 Ekser B, Kumar G, Veroux M, Cooper DK. Therapeutic issues in the treatment of vascularized xenotransplants using gal-knockout donors in nonhuman primates. Curr Opin Organ Transplant 2011; 16: 222-230

40 Mohiuddin MM, Singh AK, Corcoran PC, Hoyt RF, Thomas ML 3rd, Ayares D, Horvath KA. Genetically engineered pigs and target-specific immunomodulation provide significant graft survival and hope for clinical cardiac xenotransplantation. J Thorac Cardiovasc Surg 2014; 148: $1106-1113$

41 Petersen B, Ramackers W, Lucas-Hahn A, Lemme E, Hassel P, Queisser $A L$, Herrmann D, Barg-Kues B, Carnwath JW, Klose J, Tiede A, Friedrich L, Baars W, Schwinzer R, Winkler M, Niemann H. Transgenic expression of human heme oxygenase- 1 in pigs confers resistance against xenograft rejection during ex vivo perfusion of porcine kidneys. Xenotransplantation 2011; 18: 355-368

42 Oropeza M, Petersen B, Carnwath JW, Lucas-Hahn A, Lemme E, Hassel P, Herrmann D, Barg-Kues B, Holler S, Queisser AL, Schwinzer R, Hinkel R, Kupatt C, Niemann H. Transgenic expression of the human A20 gene in cloned pigs provides protection against apoptotic and inflammatory stimuli. Xenotransplantation 2009; 16: 522-534

43 Petersen B, Ramackers $W$, Tiede A, Lucas-Hahn A, Herrmann D, BargKues B, Schuettler W, Friedrich L, Schwinzer R, Winkler M, Niemann $H$. Pigs transgenic for human thrombomodulin have elevated production of activated protein C. Xenotransplantation 2009; 16: 486-495

44 Ezzelarab M, Garcia B, Azimzadeh A, Sun H, Lin CC, Hara H, Kelishadi S, Zhang T, Lin YJ, Tai HC, Long C, Wagner R, Thacker J, Murase N, McCurry $K$, Barth RN, Ayares D, Pierson $R N 3^{\text {rd }}$, Cooper DKC. The innate immune response and activation of coagulation in alpha1,3-galactosyltransferase gene-knockout xenograft recipients. Transplantation 2009; 87: 805-812

45 Poirier N, Azimzadeh AM, Zhang T, Dilek N, Mary C, Nguyen B, Tillou X, Wu G, Reneaudin K, Hervouet J, Martinet B, Coulon F, Allain-Launay E, Karam G, Soulillou JP, Pierson RN $3^{\text {rd }}$, Blancho G, Vanhove B. Inducing CTLA-4-dependent immune regulation by selective CD28 blockade promotes regulatory $\mathrm{T}$ cells in organ transplantation. Sci Translat Med 2010; 2: 17 ra10

46 Klymiuk N, van Buerck L, Bähr A, Offers M, Kessler B, Wuensch A, Kurome M, Thormann M, Lochner K, Nagashima H, Herbach N, Wanke R, Seissler $J$, Wolf E. Xenografted islet cell clusters from INSLEA29Y transgenic pigs rescue diabetes and prevent immune rejection in humanized mice. Diabetes 2012; 61: 1527-1532

47 Del Rio ML, Seebach JD, Fernandez-Renedo C, Rodriguez-Barbosa JI. ITIM-dependent negative signaling pathways for the control of cellmediated xenogeneic immune responses. Xenotransplantation 2013; 20: 397-406

48 Ding Q Lu L, Zhou X, Zhou Y, Chou KY. Human PD-L1-overexpressing porcine vascular endothelial cells induce functionally suppressive human CD4+CD25hiFoxp3 + Treg cells. J Leukoc Biol 2011; 90: 77-86

49 Plege-Fleck A, Lieke T, Römermann D, Düvel H, Hundrieser J, Buermann $A$, Kraus L, Klempnauer J, Schwinzer R. Pig to rat cell transplantation: reduced cellular and antibody responses to xenografts overexpressing PD-L1. Xenotransplantation 2014; Jul 9 doi:10.1111/xen.12121 [Epub ahead of print]

50 Waldmann H, Adams E, Fairchild P, Cobbold S. Regulation and privilege in transplantation tolerance. J Clin Immunol 2008; 28: 716-725

51 Muller YD, Golshayan D, Ehirchiou D, Wekerle T, Seebach JD, Buhler LH. $\mathrm{T}$ regulatory cells in xenotransplantation. Xenotransplantation 2009; 16: $121-128$

52 Inverardi L, Pardi R. Early events in cell-mediated recognition of vascularized xenografts: cooperative interactions between selected lymphocyte subsets and natural antibodies. Immunol Rev 1994; 141: 71-93

53 Schneider MK, Seebach JD. Current cellular innate immune hurdles in pig-to-primate xenotransplantation. Curr Opin Organ Transplant 2008; 13: 171-177 
54 Li S, Waer M, Billiau AD. Xenotransplantation: role of natural immunity. Transplant Immunol 2009; 21: 70-74

55 Weiss EH, Lilienfeld BG, Muller S, Muller E, Herbach N, Kessler B, Wanke $R$, Schwinzer R, Seebach JD, Wolf E, Brem G. HLA-E/human beta2-microglobulin transgenic pigs: protection against xenogeneic human anti-pig natural killer cell cytotoxicity. Transplantation 2009; 87: 35-43

56 Marigliano M, Bertera S, Grupillo M, Trucco M, Bottino R. Pig-to-nonhuman primates pancreatic islet xenotransplantation: an overview. Curr Diab Rep 2011; 11: 402-412

57 Goto M, Tjernberg J, Dufrane D, Elgue G, Brandhorst D, Ekdahl KN, Brandhorst H, Wennberg L, Kurokawa Y, Satomi S, Lambris JD, Gianello $P$, Korsgren O, Nilsson B. Dissecting the instant blood-mediated inflammatory reaction in islet xenotransplantation. Xenotransplantation 2008; 15: 225-234

58 Vaithilingam $V$, Tuch BE. Islet transplantation and encapsulation: an update on recent developments. Rev Diabetic Studies 2011; 8: 51-67

59 Ludwig B, Zimerman B, Steffen A, Yavriants K, Azarov D, Reichel A, Vardi P, German T, Shabtay N, Rotem A, Evron Y, Neufeld T, Mimon S, Ludwig $S$, Brendel MD, Bornstein SR, Barkai U. A novel device for islet transplantation providing immune protection and oxygen supply. Horm Metab Res 2010; 42: 918-922
60 Ludwig B, Rotem A, Schmid J, Weir GC, Colton CK, Brendel MD, Neufeld T, Block NL, Yavriyants K, Steffen A, Ludwig S, Chavakis T, Reichel A, Azarov $D$, Zimermann B, Maimon S, Balyura M, Rozenshtein T, Shabtay N, Vardi $P$, Bloch $K$, de Vos P, Schally AV, Bornstein SR, Barkai U. Improvement of islet function in a bioartificial pancreas by enhanced oxygen supply and growth hormone releasing hormone agonist. Proc Natl Acad Sci USA 2012; 109: 5022-5027

61 Barkai U, Weir GC, Colton CK, Ludwig B, Bornstein SR, Brendel MD, Neufeld T, Bremer C, Leon A, Evron Y, Yavriyants K, Azarov D, Zimermann $B$, Maimon S, Shabtay N, Balyura M, Rozenshtein T, Vardi P, Bloch K, de Vos $P$, Rotem $A$. Enhanced oxygen supply improves islet viability in a new bioartificial pancreas. Cell Transplant 2013; 22: 1463-1476

62 Neufeld T, Ludwig B, Barkai U, Weir GC, Colton CK, Evron Y, Balyura M, Yavriyants K, Zimermann B, Azarov D, Maimon S, Shabtay N, Rozenshtein T, Lorber D, Steffen A, Willenz U, Bloch K, Vardi P, Taube R, de Vos $P$, Lewis EC, Bornstein SR, Rotem A. The efficacy of an immunoisolating membrane system for islet xenotransplantation in minipigs. PLoS One 2013; 8: e70150

63 Ludwig B, Reichel A, Steffen A, Zimerman B, Schally AV, Block NL, Colton CK, Ludwig S, Kersting S, Bonifacio E, Solimena M, Gendler Z, Rotem A, Barkai U, Bornstein SR. Transplantation of human islets without immunosuppression. Proc Natl Acad Sci USA 2013; 110: 19054-19058 